\title{
KRITIK SANAD HADIS \\ (Studi Sunan Ibnu Majah, Kitab az-Zuhud)
}

\section{Zaenal Arifin}

Sekolah Tinggi Ilmu Tarbiyah Sunan Giri Trenggalek arzafin@gmail.com

\section{Abstract}

There are three elements of the validity of the method in determining the authenticity of a Hadith:it's connection by isnad, credibility of the narrator, syuż̇̇z and 'illah. The focus of the study in this article is to examine the isnad hadith narrated by Ibn Majah through companions 'Abd ar-Rahman (Abu Hurayrah) found in Sunan Ibn Majah, Kitab al-Zuhud, hadithnumber 4102. it's done by takhreej of hadith and i'tibar, it recorded by researchers the quality of the narrators and its connectioned, and the possibility of checking by syużüz and 'illah.

Finally seen that entire hadith is created by siqat and its isnaad muttaşil (connected) from the Prophet Muhammad to the last creature and Ibn Majah as mukharrij al-hadith, and not found the presence of syuziżz or 'illah, so that have the best quality that can enter the category of hadith is hasan li ghairih.

Keywords: Isnad Criticism, Hadith, Kitab al-Zuhud 


\section{Abstrak}

Terdapat tiga unsur kaedah kesahihan dalam menentukan keotentikansuatuhadis, yaituketersambungansanad, kredibilitas rawi, serta syużü̇̇ (kejanggalan), dan 'illah (kecacatan). Fokus kajian dalam artikel ini adalah meneliti sanad hadis yang diriwayatkan oleh Ibnu Majah melalui sahabat 'Abd ar-Rahman (Abu Hurairah) yang terdapat pada Sunan Ibnu Majah, Kitab al-Zuhud, nomor hadis 4102. Yakni dengan dilakukan takhrij hadis dan i'tibar, diteliti kualitas perawi dan ketersambungan sanadnya, dan dilakukuan pengecekan kemungkinan adanya syu̇ī̇̇ dan 'illah.

Akhirnya terlihat bahwa seluruh periwayat hadis tersebut bersifat śiqat dan sanadnya muttaşil (tersambung) dari Nabi Muhammad SAW sampai kepada periwayat terakhir Ibnu Majah yang sekaligus sebagai mukharrij al-hadis, dan tidak ditemukan adanya syużüż (kejanggalan) ataupun 'illah (cacat), sehingga kwalitasnya bisa masuk kategori hadis hasan li ghairih.

Kata Kunci: Kritik sanad, Hadis, Kitab al-Zuhud 


\section{A. PENDAHULUAN}

$\mathrm{M}$ unculnya istilah Kutub as-Sittah atau istilah Kutub alTis'ah memberiimplikasi pada pemahaman bahwakitab selain keduanya merupakan kumpulan kitab hadisyang diragukan keotentikannya baik dari segi sanad maupun matan. Apakah pengumpulan hadis dalam keduanya merupakan suatu yang harus kita terima tanpa penelitian lebih lanjuttentang kualitas sanad dan matan?

Secara garis besar, ada tiga unsur kaedah kesahihan hadis dalam menentukan keotentikan suatu hadis, yaitu ketersambungan sanad, kredibilitas rawi ('adil dan dhabit), syuż $\bar{u} \dot{z}$ (kejanggalan), dan 'illat (kecacatan). Ketiga cara ini dapat digunakan sekaligus dalam menentukan keotentikan hadis dari segi sanadnya, tetapi penelitian matan cukup menggunakan dua cara terakhir untuk meneliti keotentikannya. ${ }^{1}$

Dalam artikel ini penulis meneliti sanad salah satu hadis yang diriwayatkan oleh Ibnu Majah dalam kitabnya, Sunan Ibnu Majah, yang menempati tingkat keenam dari Kutubal-Sittah yang terkenal banyak terdapat zawa'id, yaitu tulisan hadis yang tidak terdapat pada lima kitab hadis lainnya (al-Bukhari, al-Muslim, al-Tirmidzi, al-Nasa'i, Abu Dawud). Adapun hadis tersebut adalah riwayat Ibnu Majah melalui sahabat 'Abd ar-Rahman (Abu Hurairah) yang terdapat pada Sunan Ibnu Majah, Kitab al-Zuhud, nomor hadis 4102.

Adapun metode yang digunakan dalam meneliti kesahihan sanad hadis riwayat Ibnu Majah ini melalui langkah-langkah, yaitu:

1. Melakukantakhrijhadis(penulisan teks hadis, artidansusunan sanad)

2. Melakukan i'tibar

3. Meneliti kualitas perawi dan ketersambungan sanad

4. Menelitikejanggalan (syużùz) dan kecacatan ('illah)

5. Merumuskan hasil penelitian (kesimpulan)

\footnotetext{
${ }^{1}$ M. Syuhudi Ismail, Metodologi Penelitian Hadis (Jakarta: Bulan Bintang, 1992), h. 64-65. LihatFathur Rahman, Ikhtisar Musthalahul Hadis (Bandung: PT. Ma'rif, 1991), h. 99. dan bandingkan M. Ahmad dan M. Musdzakir, Ulumul Hadis Untuk Fakultas Tarbiyah Komponen MKDK (Bandung: CV Pustaka Setia, 2004), h. 126-127
} 


\section{B. PEMBAHASAN}

\section{Teks Hadis Sunan Ibnu Majah, Kitab al-Zuhud, Nomor 4102}

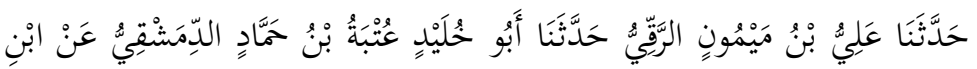

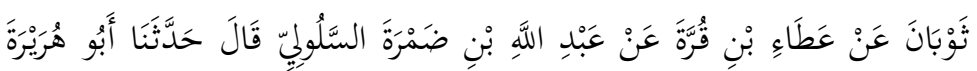

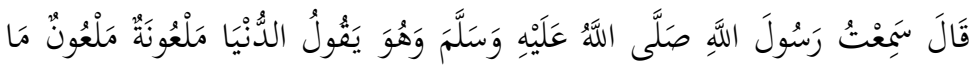

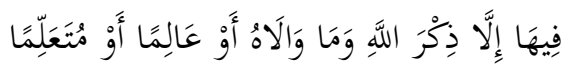

Ali bin Maimun ar-Riqqy berkata kepada kami, Abu Khalid Utbah bin Hammad ad-Dimasyqy berkata kepada kami dari Ibn Tsauban dari Atha'bin QurrahdariAbdillahbin Dhamrahas-Salulyberkata Abu Hurairah berkata kepada kami: "Aku mendengar Rasulullah SAW., bersabda:" Dunia itu dilaknati dan dilaknati apa yang di dalamnya selain ingat kepada Allah, perbuatan yang disenangi Allah, orang pandai dan orang yang belajar".

Adapun skema sanad hadis Ibnu Majah no. 4201 di atas adalah:

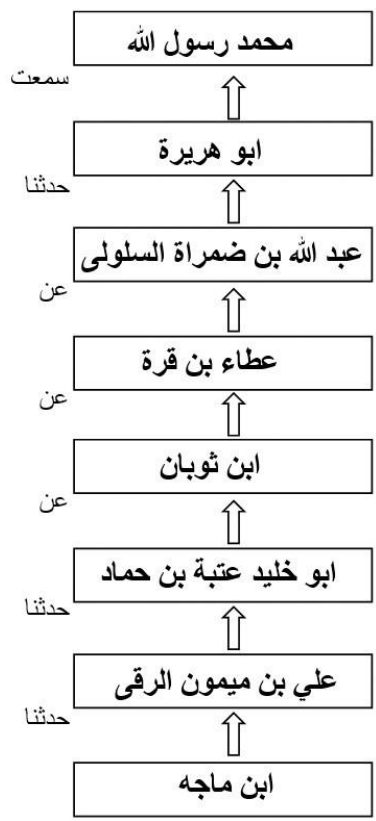


Dari susunan sanad di atas, hadis riwayat Ibnu Majah tersebut melalui urutan sebagai berikut:

(1) Periwayat I : Abu Hurairah

(2) Periwayat II : Abdullah bin Dhamrah as-Saluli

(3) Periwayat III: Atha' bin Qurrah

(4) Periwayat IV: Ibn Tsauban

(5) Periwayat V : Abu Khulaid 'Utbah bin Hammad

(6) Periwayat VI: Ali bin Maimun al-Raqi

(7) Periwayat VII : Ibnu Majah

\section{Melakukan I'tibar}

Selain diriwayatkan Ibnu Majah, hadis ini juga diriwayatkan oleh at-Tirmidzi (no. 2244) dan ad-Darimi (no. 324).

Berikut ini redaksi hadis tersebut:

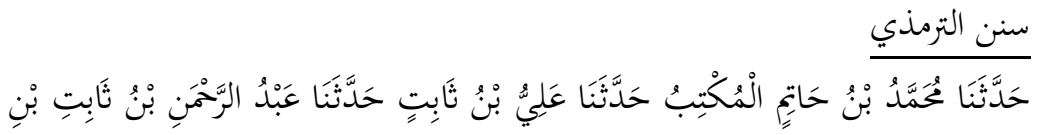

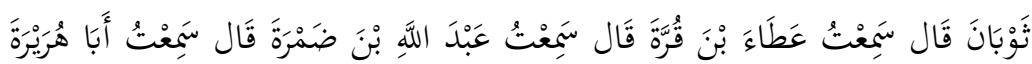

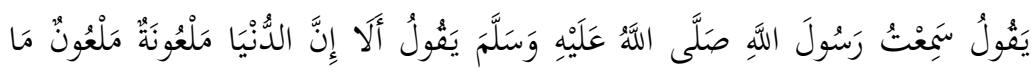

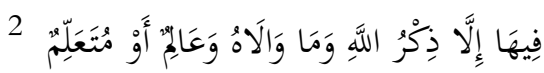

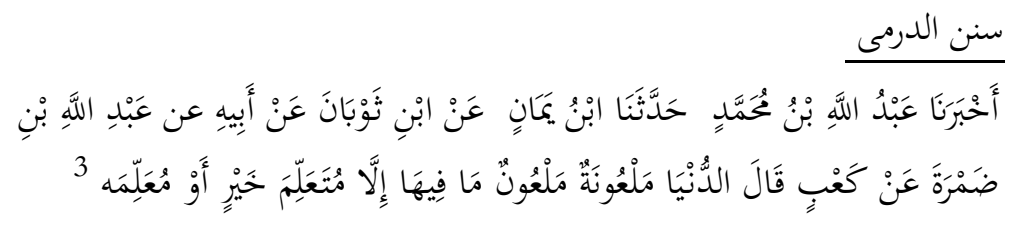

Adapun skema sanad dari keseluruhan sanad hadis riwayat Ibnu Majah dan selainnya sebagai berikut:

\footnotetext{
${ }^{2}$ CD-Rom, Mausu'ah al-Hadis al-Syarif al-Kutub al-Tis'ah.

${ }^{3}$ CD-Rom, Mausu'ah al-Hadis al-Syarif al-Kutub al-Tis'ah.
} 

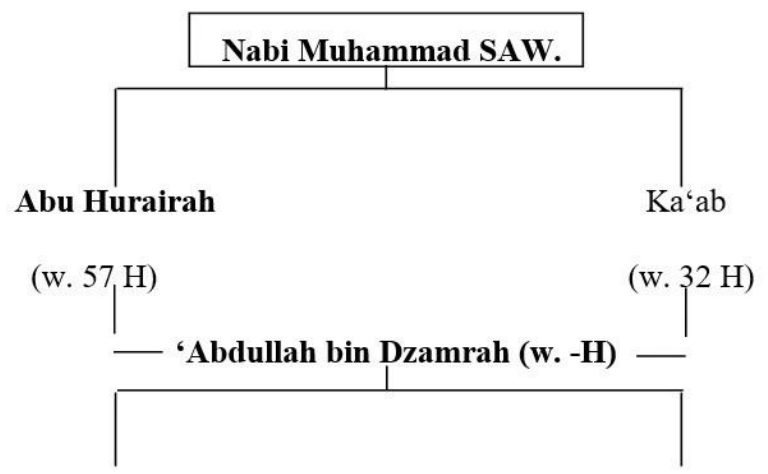

'Atha' bin Qurrah Tsabit bin Tsuban al-Syami
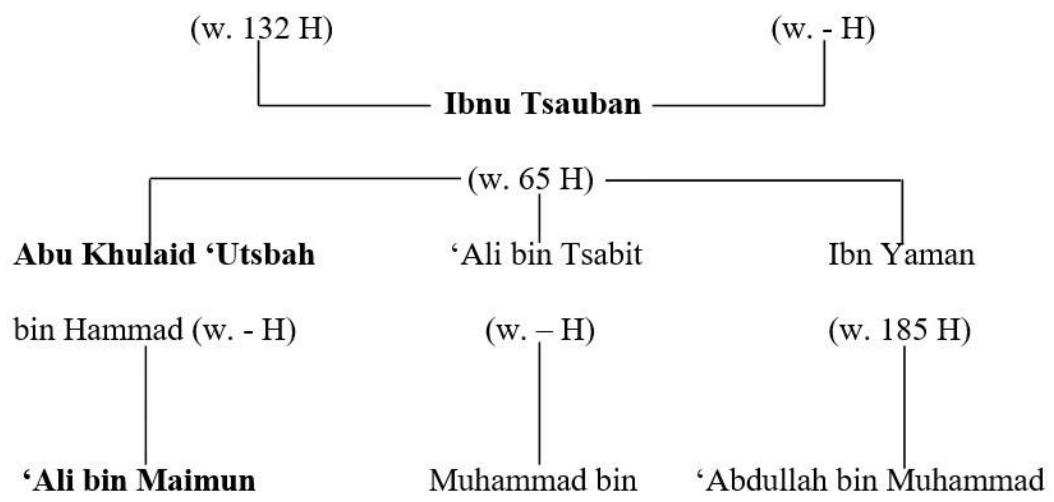

\section{Meneliti Kualitas Periwayat dan Persambungan Sanad}

Dalam meneliti kualitas periwayat dan ketersambungan sanad, akan disampaikan berbagai biografi periwayat hadis dari mulai mukharrij sampai periwayat pertama. Kemudian akan diteruskan dengan melihat kualitas rawi dari segi keshahehan rawi dan diakhiri dengan melihat ketersambungan sanad.

1. Ibnu Majah

a. Nama Lengkap : Abu 'Abdillah Muhammad bin Yazid al-Raba'i al-Qazmini

b Tingkatan: Mukharrij al-hadis

c. Lahir : Iraq, $209 \mathrm{H} / 824 \mathrm{M}$ 
d. Wafat: Iraq, 20 Ramadhan 273 H/18 Februari 887 M

e. Nasab : Yazid atau Majah Maula Rab'at

f. Guru dan Muridnya:

1). Guru: Ali bin Muhammad al-Tanafasi, Abu Bakar bi 'Ali al-Syaibah, Muhammad bin 'Abdullah bin Numaya, 'Ubdah bin 'Abdullah bin 'UbdahalShaffar, Hisyam bin Amwar, Ahmad bin al-Azhar, Basyar bin Adam, al-Lays. 'Ali bin Maimun Muhammad bin Hatim al-Raqial-'Athar

2). Murid: Ibn Sibawaih, Muhammad bin 'Isa al-Saffar, Ishaq bin Muhammad, Ali bin Ibrahim bin Salamah al-Qattan, Ahmad bin Ibrahim, Sulaiman bin Yazid, Ibrahim bin Dinar al-Jarasyi al-Hamdani.

g. Pandangan kritikushadis:

Ibn Hajar : ia seorang ahli hadis dalam tingkatan hafidh dan ahad al-'Aimmah

Ibnu Katsir : ia adalah penulis kitab al-Sunan yang termasyur

Al-Hafidz Abu Yala al-Khalil : ia adalah seorang yang śiqah dan ḍābiț serta 'alim dalam bidang hadis

Adz-Dzahabi : Ia pemilik kitab al-Sunan dan seorang yang hafidh.

Dari semua kritikus hadis menyatakan bahwa Ibnu Majah seorang yang dlabith (kuat hafalan) sehingga ia seorang al-Hafidh dalam hadis. Selain kuat hafalan, ia juga śiqah (orang yang terpercaya). Istilah śiqah, dlabith dan hafidh digunakan oleh Ibnu ash-Shalah, anNawawi untuk menunjukkan ta'dil tingkat pertama, al-Harawi untuk tingkat kedua, dan Ibn Hajar dan asSuyuthi menggunakannya untuk ta'dil tingkat ketiga. Ibnu Abi Hatim ar-Razi, adz-Dzahabi, dan al-'Iraqi tidak menggunakan istilah dlabith dan hafidh, tetapi menggunakan lafadz śiqah. Ibnu Abi Hatim menggunakan 
śiqat untuk ta'dil tingkat pertama, sedangkan adz-Dzahabi dan al-'Iraqi untuk tingkat kedua. ${ }^{4}$

2. 'Ali binMaimun

a. Nama Lengkap : 'Ali bin Maimun Muhammad bin Khatim al-Raqi Abu al-Hasan al-'Athar.

b. Tingkatan : Kabar tab'u al-ittiba'

c. Lahir: $-\mathrm{H}$

d. Wafat: $245 \mathrm{H}$, Abu 'Alial-Harani: $246 \mathrm{H}$, selainnya 247 H. ${ }^{5}$

e. Nasab :Ar-Raqi

f. Guru dan Muridnya

1). Guru: Ishaq bin Ibrahim, Hafsh bin Ghiyats bin Talq, Bisri bin al-Sari bin al-Harist bin 'Amin, Khalid bin Hiyan, Sa'id bin Maslamah bin Abi 'Imran Maimun, 'Abdullah bin Yazid, 'Abd al-Majid bin 'Abd al-Aziz bin Ali Rawad, 'Abd al-Walid bin Shalih, 'Utbah bin Hammad bin Khulaid, 'Ustman bin 'Abd ar-Rahman bin Muslim, Muhammad Khazim, Muhammad bin 'Ubaid bin AbiUmayyah, Mukhalid bin Yazid, Mu'ammar bin Sulaiman, Waki‘ bin al-Jarrah bin Malih.

2). Murid: An-Nasa'i, Ibnu Majah, Abu 'Urubah, Abu Zar'ah, Abu Hatim, Muhammad bin 'Abd al-malik al-Daqiqi, Baq bin Mukhalid, Ibn Abi 'Ashim, 'Abdan al-Ahwazi, al-Ma'mari, al-Hasan bin Ahmad bin Ibrahim bin Qais, Abu 'Urwah al-Harani.

g. Pandangan kritikus hadis: ${ }^{6}$

Abu Hatim al-Razi : Śiqah

An-Nasa'i : La ba'sabih

Ibnu Hibban : Memasukkan dalam kitab ats-Śiqat-nya.

Dari pandangan kritikus hadis, dapat disimpulkan

5 IbnHajaral-'Asqalani, Tahdhibal-TahdhibJuzVII(Beirut:DarShadir,t.t.), h. 389.

6 Ibnu Hajar al-'Asqalani, Tahdzib al-Tahdzib ..., h. 389. 
bahwa kualitas atau kredibilitas 'Ali bin Maimun sebagai perawi dapat diterima walaupun berbeda tingkatannya menurut berbagai pendapat. Abu Hatim ar-Razi dan Ibnu Hibban memandang sebagai perawi śiqah. lafadzśiqah ini digunakan oleh Ibnu Hatim, Ibnu Shalah dan an-Nawawi untuk ta'dil tingkat pertama. Sedangkan Ibnu Hajar al'Asqalani, as-Suyuthi, adz-Dzahabi, al-'Iraqi dan al-Harawi untuk menunjukkan seorang perawi itu ta'dil tingkat kedua. ${ }^{7}$ Berbeda dengan Abu Hatim ar-Razi dan Ibnu Hibban, an-Nasa i menyatakan la ba's bih (tida ada cacat padanya) dimanalafadzini digunakan oleh Ibnu HatimarRazi, Ibnu Shalah dan an-Nawawi pada ta'dil tingkat kedua, al-Harawi pada tingkat ke tiga , Ibnu Hajar al-'Asqalani, Ibnu Shalah dan as-Suyuthi untuk tingkat keempat dan al'Iraqi menggunakannya untuk tingkat kelima. ${ }^{8}$

Hubungan sanad antara 'Ali bin Maimun dan Ibnu Majah terdapat ketersambungan (muttashil) yaitu, pertama ada hubungan antara guru dan murid. Kedua, dilihat dari jarak umur keduanya menunjukkan bahwa pada saat 'Ali bin Maimun meninggal (245/246/247 H), umur Ibnu Majah sekitar 36-38 tahun dihitung dari kelahirannya (209H). Ketiga, melihatdari hubungan guru dan murid jelas menunjukkan bahwa keduanya bertemu langsung (mua 'sarah wa liqa') dengan penggunaan metode periwayatan as-sama', yaitu lafadz حدثنا (haddatsana) di mana menurut Ibnu Hajar al-'Asqalani lafadz haddatsana pada umumnya menunjukkan bahwa periwayat mendengar sendiri. ${ }^{9}$

\section{3. 'Utbah bin Hammad}

a. NamaLengkap : 'Utbah bin Hammad bin Khulaid alDimasyaqi al-Qari'i

b. Tingkatan : Kabar tab'ual-ittiba'

7 Suryadi, Metodologi..., h. 46-47,49-52, dan 53.

8 Ibid., h. 46-48, 51, 53, dan 54.

9 Syuhudi Isma'il, Kaedah Kesahihan Sanad Hadis: Telaah Kritik dan Tajam dengan Pendekatan Ilmu Sejarah (Jakarta: Bulan Bintang, 1988), h. 60. 
c. Lahir : $-\mathrm{H}$

d. Wafat : Syam, -H (tidak diketahui)

e. Nasab : Al-Hakimad-Dimasyqi

f. Guru dan Muridnya

1). Guru: 'Abd ar-Rahman bin Tsabit bin Tsauban, 'Abd ar-Rahman bin Abial-Zanad, Malik, Laits, azZubaidi, Wadhin bin Atha', Sa 'id bin Basyir, Sa'id bin Abd al-'Aziz, Tha'ifah.

2). Murid: Ali bin Maimun, Ayub bin Muhammad alWazan, Hisyam al-Azraq

g. Pandangan kritikus hadis: ${ }^{10}$ Abu 'Ali al-Naisaburi : Śiqat Al-Khatib :Śiqah

Abu Hatim : Syaikh (seorang guru) Ibnu Hibban: memasukkan dalamkitabats-Śiqat-nya.

Menurut pandangan kritikus hadis, kredibilitas 'Utbah bin Hammad sebagai perawi tidak diragukan (men-ta'dilnya). Halinidibuktikandenganberbagaipandangantentang kualitas śiqah oleh Abu 'Ali al-Naisaburi, al-Khatib, Ibnu Hibban dan syaikh menurut Abu Hatim ar-Razi. Istilah śiqat digunakan oleh para kritikus hadis untuk menunjukkan kredibilitas seorang perawi pada ta`dil tingkatan pertama (Ibnu Hatim, Ibnu Shalah dan an-Nawawi)dan kedua (Ibnu Hajar al-'Asqalani, as-Suyuthi, adz-Dzahabi, al-'Iraqi dan al-Nawawi). ${ }^{11}$ Sedangkan penggunaan istilah syaikh oleh Ibnu Hatim ar-Razi, Ibnu Shalah dan Suyuthi untuk menyatakan perawi ta'dil tingkat ketiga atau digunakan oleh al-Dzahabi, al-'Iraqi, dan al-Harawi untuk ta'dil tingkat keempat atau digunakan oleh Ibnu Hajar al-'Asqalani dan as-Suyuthi untuk $t a^{\prime}$ dil tingkat kelima. ${ }^{12}$

Ketersambungan (ke-muttashilan) sanad antara 'Utbah bin Hammad dan 'Ali bin Maimun nampak terlihat dari

10 Ibnu Hajar al-'Asqalani, Tahdhib al-Tahdhi ..., h. 95.

11 Suryadi, Metodologi..., h. 46-47, 49-52, dan 53.

12 Ibid., h. 46-49, 51, 53, dan 55. 
berbagai data yang bisa dilacak tentang keduanya. Pertama, adanya hubungan guru dan murid menurut para ahli sejarah rijal al-hadits. Kedua, tahun lahir dan wafat 'Utbah bin Hammad tidak diketahui secara pasti, namun ditemukan bukti bahwa keduanya hidup semasa dengan tingkat samasama merupakan Kabar tab'u al-ittiba'. Ketiga, melihat hubungan guru dan murid dikuatkan dengan lambang periwayatan dalam hadis ini adalah حدثنا (haddatsana), yang dianggap al-Khatib al-Baghdadi bersifat umum, yaitu ada kemungkinan periwayat yang bersangkutan tidak bertemu langsung, tetapi menurut Ibnu Hajar al-'Asqalani lafadz hadasana pada umumnya menunjukkan bahwa periwayat mendengar sendiri. ${ }^{13}$ Dari sini jelas menunjukkan adanya ketersambungan sanad.

4. 'Abd ar-Rahman

a. Nama Lengkap : 'Abd ar-Rahman bin Tsabit bin

Tsaubanal-Syami/al-'Anasial-Zahidial-Dimsyaqi

b. Tingkatan : Kabar al-ittiba'

c. Lahir : $75 \mathrm{H}$

d. Wafat :Baghdad, 165 Hpadaumur90 tahun ${ }^{14}$

e. Nasab : Al-'Anasi

f. Guru dan Muridnya

1). Guru: al-Syami (ayahnya) Tsabit bin Tsuban, Hasan bin 'Atiyyah, 'Abdullah bin al-Fadhl bin al-'Abbas bin Rabi'ah, 'ubdah bin Abi Lubabah, 'Atha' bin Qurrah, 'Amru bin Dinar al-Astiram, 'Amin bin Hana'i, al-Nu'man bin Rasyid, Nafi'.

2). Murid: Baqiyyah bin Walid bin Shaid, Zaid bin alHubbab bin al-Rayan, Zaid bin Yahya bin 'Ubaid, Sulaiman bin Dawud bin al-Ja'ud, 'Abd al-Qudus bin al-Hajjaj, 'Abd al-Malik bin 'Amru, 'Utbah bin Hammad bin Khulaid, 'Ustman bin Sa'id bin Dinar, 'Asham bin Khalid, 'Asham bin 'Ali, 'Ali bin Tsabit,

13 Syuhudi Isma'il, Kaedah Kesahihan Sanad Hadis ..., h. 59-60.

14 Al-Dzahabi, Mizan al-I'tidal fi Naqd al-Rijal, Juz II (Tahqiq) 'Ali Muhammad al-Bajawi (T.t.p.: Dar Akhya'al-Kutub al-'Arabiyyah, t.t.), h. 552. 
'Alibin 'Tyas bin Muslim, al-Khalq, Muhammad bin Yazid, Muhammad bin Yusuf bin Waqid bin 'Ustman, Musa bin Dawud, Hisyam bin al-Qasim bin Muslim bin Muqsim, al-Walid bin Muslim, Yahya bin Yaman. Abu Na'im, 'Ali bin Anas , Baqiyyah, al-Furyan, 'Ali bin Ja'd.

g. Pandangan kritikus hadis: ${ }^{15}$

Duhaim dan selainnya : Śiqat dan sebagian lain: layin Abu Dawud dan Sajastani: Kana fih salamah Abu Hatim al-Razi : Śiqat

Shalih jazirah : Shaduq Ibn Mu'in : Laisa bih ba'sun tetapi menurut riwayat dari 'Ustman bin Sa'id masuk kategori dha' if (lemah) An-Nasa'i : Laisa bi al-qawi

Ahmad bin Hubair : Lam yakun bi al-qawi fi al-hadits Ahmad : Ahaditsuhu munkar Ibnu 'Adi : Yaktub haditsuh 'ala dha'fih

Al-Auza'i : Rufi' "anh al-qalam ai (annahu) junna (pikun)

Para kritikus hadis terbagi menjadi dua kelompok mengenai kredibilitas 'Abd ar-Rahman bin Tsabit bin Tsauban. Kelompok pertama, Duhaim dan Abu Hatim ar-Razi memandang sebagai orang śiqat. Śiqat dalam peringkat $t a^{\prime}$ dil berada padaurutan pertamamenurutIbnu Shalah dan an-Nawawi, sedangkan menurut Ibnu Hajar al'Asqalani, as-Suyuthi, adz-Dzahabi, al-'Iraqi, dan al-Harawi pada urutan kedua. Shalih Jazirah menyatakan shaduq dan Ibnu Mu'in memandangnya laisa bihi ba's sebagai lafadz ta'dil tingkat ketiga menurut al-Dzahabi, al-'iraqi dan alHarawi, sedangkan tingkat tingkat keempat menurut Ibnu hajar al-'Asqalani dan as-Suyuthi. ${ }^{16}$ Kelompok kedua, alNasa'i dan Ahmad bin Hubair memandang Ibnu Tsauban: laisa bi al-qawi, Ahmad: ahaditsuh munkar, Ibn 'Adi: yaktub haditsuhu 'ala dha'fih, dan al-Auza'i menyatakan rufi'a 'anh

15 Adz-Dzahabi, Mizan al-I'tidal..., h. 551.

16 Suryadi, Metodologi ..., h. 46-47, 49-52, dan 53. 
al-qalam ai (annah) junna (pikun). Laisa bi al-qawi (bukan orangyang kuat) adalahlafadzjarh tingkat ketiga menurut Ibnu Hatim, Ibnu Shalah dan al-Nawawi; tingkat kelima bagial-'Iraqi dan al-Harawi; dan tingkat keenam bagi Ibnu Hajar al-'Asqalani dan as-Suyuthi. Ahmad bin Hanbal berpendapat bahwa ahaditsuh munkar dan Ibn 'Adi mendha'if-kannya. ${ }^{17}$ Keduaistilah inibiasanya digunakan oleh para kritikus hadis untuk menempatkan padajarh tingkat keempat dankelima.

Ada satu pandangan yang perlu diperhatikan, yaitu al-Mali dan Ibnu Hajar yang menyatakan bahwa 'Abd arRahman bin Tsauban mengalami perubahan (kekacauan) diakhir kehidupannya. ${ }^{18}$ yang diperkuat oleh beberapa riwayat. Al-Walid bin Mazid meriwayatkan dari al-Auza'i bahwaia telah menulis kepada surat kepada Ibn Tsauban sebagai berikut: "Sungguh engkau sebelum wafatnya ayahmu berpandangan bahwa meninggalkan shalat itu haram, sekarang engkau berpendapat: ترك اجلمعةواجلماعة (meninggalkan shalat jum'at dan jama'ah boleh hukumnya). Al-'Abbas bin Walid bin Mazid meriwayatkan dari ayahnya (al-Walid bin Mazid) bahwa suatu malam ia bersama al-Auza'i dan para sahabat mereka serta Ibn Tsauban, kemudian ayahku berkata kepada Ibn Tsauban: "Hunuslah pedangmu"?, Ibn Tsauban berkata: "Innallah ta'ala qad Jadda fa Jaddu". ${ }^{19}$ Perubahan inilah yang kemungkinan besar memberi landasan kuat kepada alAuza'i sehingga hadis Ibnu Tsauban tidak bisaditerima (rufi'a anh al-qalam) dengan alasan junna (pikun).

Jikaal-Malidanal-Auzaiinibenar, makaadaduaasumsi yang bisa diajukan. Pertama, jika semua riwayat perubahan itu benar, kemungkinan besar Ibnu Tsauban bin Tsabit pada awalnya adalah orang yang memiliki kredibilitas śiqat,

\footnotetext{
17 Suryadi, Metodologi ..., h. 59, 62, 64, dan 67.

18 CD-ROM, Mausu'ah al-Hadits al-Syarifal-Tis'ah; DVD, al-Maktabah al-Syamilah al-Ihdar alTsani.

19 Adz-Dzahabi, Mizan al-I'tidal ..., h. 551.
}

HIKMAH, Vol. XIV, No. 2, 2018 65 
tetapi pada akhir kehidupannya disebabkan faktor usia (mencapai umur 90 tahun), dimungkinkan daya hafalan bahkan ingatan menurun sampai pada tingkat junna (pikun). Kedua, jika perubahan itu betul-betul terjadi, maka tidak mungkin 'Utbah bin Hammad bin Khulaid yang terkenal śiqat mau menjadi murid dan meriwayatkan hadis dari orang yang kacau pikirannya bahkan orang yang pikun. Oleh karena itu, beradasarkan dua asumsi tersebut, Ibnu Tsauban bin Tsabit masih dalam status kredibel atau śiqat pada saat meriwayatkan hadis ini.

Dilihat dari hubungan sanad antara 'Abd ar-Rahman bin Tsabit bin Tsauban dan 'Utbah bin Hammad bin Khulaid ada ketersambungan. Validitas ketersambungan ini dapat dilihat dari beberapa bukti yang ada, yaitu pertama, ada hubungan guru dan murid. Kedua, walaupun kapan diasumsikan keduanya bertemu karena tahun lahir/wafat 'Utbah bin Hammad bin Khulaid tidak ditemukan, namun ada satu riwayat yang menyatakan bahwa 'Utbah bin Hammad bin Khulaid berkumpul dengan gurunya selama kurang lebih 60 tahun. ${ }^{20} \mathrm{Hal}$ ini memperkuat satu bukti bahwa mereka pernah bertemu secara langsung (liqa'). Sedangkan ketiga, walaupun tahammul wa al-'ada'-nya hanya dengan lafadz 'an (عن) dan ada yang berpendapat bahwa 'an itu menunjukkan keterputusan sanad, tetapi dimasukkan kemetode as-sama', asal memenuhi beberapa syarat, (1) tidak teradapat tadlis (penyembunyian informasi); (2) antar periwayat yang menggunakan 'an dimungkinkan bertemu; dan Malik bin Anas, Ibnu 'Abd al-Barr dan al-'Iraqi menambah satu lagi syarat, yaitu (3) periwayatnya haruslah orang-orang yang terpercaya. ${ }^{21}$ Dari ketiga syarat ini dapat dikatakan ketiganya terdapat pada 'Abd ar-Rahman bin Tsabit bin Tsauban dan 'Utbah bin Hammad bin Khulaid. Oleh karena itu ketersambungan sanad bisa dikatakan akurat.

20 Ibn Hajar al-'Asqalani, Tahdhib al-Tahdhib, Juz VII ..., h. 95.

21 Syuhudi Isma'il, Kaedah Kesahihan Sanad Hadis ..., h. 70. 
5. Ata' bin Qurrah
a. Nama Lengkap : Atha' bin Qurrah as-Saluli ad- Dimsyaqi
b. Tingkatan : Lam talik al-shahabat (tidak bertemu sahabat)
c. Lahir : -
d. Wafat : Damsyiq, $132 \mathrm{H}$.
e. Nasab : As-Salulial-Dimsyaqi
f. Guru dan Muridnya:

1). Guru: az-Zuhri, 'Abdullah bin Dhamrah as-Saluli, Abi Makramah as-Sa'idi
2). Murid:Abdar-Rahmanbin Tsabitbin Tsauban, Abd ar-Rahman bin Yazid bin Jabir, al-Syami.

g. Pandangan kritikus hadis: ${ }^{22}$

Al-Auza'i :Śiqat

AbuZahrah:'Abid

Ibn Hibban : Memasukkannya dalam kitab ats-Śiqatnya

Adz-Dzahabi : śiqat

Ibn Abu al-Hasan bin Sami' : Tingkat keempat dari Syamiyyin (ulama Syam)

Alibinal-Madini:laa'rafahu (sayatidakmengetahuinya)

Para kritikus hadis banyak yang menyatakan bahwa 'Atha' bin Qurrah as-Saluli al-Dimsyaqi merupakan orang yang śiqat, seperti al-Auza'i, Ibn Hibban dan adz-Dzahabi. Siqat dalam peringkat ta`dil berada pada urutan pertama menurut Ibnu Hatim al-Razi, Ibnu Shalah dan an-Nawawi. Sedangkan menurut Ibnu Hajar al-'Asqalani, as-Suyuthi, adz-Dzahabi, al-'Iraqi, dan al-Harawi pada urutan kedua. ${ }^{23}$ Adapun mengenai pernyataan al-Madini Syami:"laa'rafahu (saya tidak mengetahuinya)", bukan dalam masalah kualitas pribadinya sebagai orang yang kredibel atau tidak,

22 Al-Dhahabi, al-KasyiffiMa'rifahman lahu Riwayah fial-Kutubal-Sittah, JuzII (Tahqiq) ‘Azzad 'Ali 'And 'Atiyyah dan Musa M. 'Ali al-Musyi (T.t.p.: Dar al-Kutub al-Haditsah, t.t.), no. 3854, h. 266. Lihat. Ibn Hajar al-'Asqalani, Tahdhib al-Tahdhib, Juz VII ..., h. 210-211.

23 Suryadi, Metodologi ..., h. 46-47, 49-52, dan 53. 
namun berkaitan dengan masalah keberadaan 'Atha' bin Qurrah as-Saluli di daerah Syam. ${ }^{24}$ Dari beberapa buktibukti di atas, ditambah dengan pernyataan Ibrahim al-Ja'fi al-Bukhari bahwa ia adalah raji' al-śiqa ${ }^{25}$ dan pengakuan Abu Zahrah bahwa ia adalah seorang 'abid (ahli ibadah), maka tidak diragukan lagi bahwa ia adalah seorang yang kredibilitasnya tidak diragukan lagi.

Mengenai persambungan sanad, tidak ditemukan halhal yang meragukan akan ke-muttaşilan-nya. Pertama, para ahli menyatakan ada hubungan guru dan murid antara. Kedua, dilihat dari umur 'Atha' bin Qurrah as-Saluli adDimsyaqi (w. 132 H), maka ketika gurunya meninggal, 'Abd ar-Rahman bin Tsabit bin Tsauban (W $165 \mathrm{H}$ ) berumur 57 tahun (90-33/jarak wafat keduanya) karena iaberumur sampai 90 tahun. Seseorangyang berumur 57 tahun kemungkinan belum mengalami apa yang namanya pikun, apalagi 'Abd ar-Rahman bin Tsabit bisa dipastikan menerima hadis dari 'Atha' bin Qurrah as-Saluli sebelum gurunya wafat. Ini berarti keduanya dimungkinkan bertemu atau paling tidak semasa. Ketiga, hubungan periwayatan dengan metode as-sama', walaupun hanya dengan lafadz 'an, tetapi syarat-syarat untuk diterimanya lambang periwayatan 'an tidak diragukan lagi karena keduanya tidak ada tadlīs, jelas keduanya dimungkinkan bertemu dan termasuk orang-orang terpercaya. ${ }^{26}$ Ketiga hal inilah membuktikan bahwa keduanya benar-benar ada persambungan sanad.

\section{Abdullah bin Dhamrah}

a. Nama Lengkap : 'Abdullah bin Dhamrah as-Saluli

b. Tingkatan :Wusțaminal-Tabi'in (tabi'in tengah)

c. Lahir : - H.

d. Wafat : Kufah, - H.

24 DVD, al-Maktabah al-Syamilah al-Ihdar al-Tsani.

25 Ibrahim al-Ja'fi al-Bukhari, Kitab at-Tarih al-Kabir, Jilid VI (Beirut: Dar al-Kutub al- 'Ilmiyyah, t.t.), h. 473-474.

26 Syuhudi Isma'il, Kaedah Kesahihan Sanad Hadis ..., h. 70. 
e. Nasab : As-Saluli

f. Guru dan Muridnya:

1). Guru: Abu Hurairah (Abd ar-Rahman bin Sakhr), Ka'ab bin al-Ahbar, Abi Darda'.

2). Murid: Tsabit Ibn Tsuban, Atha' bin Qurrah, Muhammad bin Muslim bin Tadris, Mujahid bin Jabbar, Dzakwan Abu Salih as-Samani, Abu azZubair al-Makki. 'Abd ar-Rahman bin Sabith

g. Pandangan kritikus hadis: ${ }^{27}$

Al-'Ajali : Mencatatnya dalam kitab aś-Śiqat, ia adalah saudaralaki-laki 'Ashim bin Dhamrah tabi' in Khufah yang śiqat

Ibn Hibban : memasukkan ia dalah kitab aś-Śiqat-nya Al-Bukhari : Ia adalah saudara lak-laki 'Ashim bin Dhamrah dan saya tidak jelas tentangnya (la yatabayyanu 'indhi) Ibnu Hajar : Ia adalah seorang yang śiqat

Secara umum para kritikus hadis menyatakan bahwa 'Abdullah bin Dhamrah as-Saluli adalah orang yang śiqah sebagaimana dinyatakan oleh al-'Ajali, Ibn Hibban, Ibnu Hajar. Dari pernyataan ini ia dikatakan urutan pertama atau kedua dari tingkatan ta'dil al-rāwi i. ${ }^{28}$ Adapun pernyataan al-Bukhari, ia tidak mengetahui tentangnya, tidak mengurangi bukti ke-śiqat-annya sebab para kritikus lain banyak mengetahui bahwa ia adalah saudara lakilaki 'Ashim bin Dhamrah tabi'in Khufah yang śiqat dan keterangan ini tidak disangkal oleh al-Bukhari sendiri.

Dari segi ketersambungan sanad antara 'Abdullah bin Dhamrah as-Saluli dan 'Atha' bin Qurrah as-Saluli tidak diragukan lagi dengan berbagai bukti yang ada, antara lain: pernyataan para ahli sejarah hadis bahwa ada hubungan guru dan murid. Selain itu kemungkinan besar selain

27 Ibn Hajar al-'Asqalani, Tahdhibal-Tahdhib Juz VII ..., h. 266-267.

28 Suryadi, Metodologi ..., h. 46-47, 49-52, dan 53. 
hubungan guru dan murid, dilihat dari kedudukan mereka sama-sama sebagai Tabi'in, maka kemungkinan mereka bertemu besar sekali. Sedangkan dilihat dari metode periwayatnnya adalah as-sama' dengan tahammul wa al'ada'-nya menggunakan lafadz 'an yang sebagian besar para kritikus hadis menyatakan bisa diterima dengan berbagai syarat, yaitu keduanya tidak ada tadlis, jelas keduanya dimungkinkan bertemu dan termasuk orang-orang terpercaya. ${ }^{29}$

7. Abu Hurairah

a. Nama Lengkap : 'Abd ar-Rahman bin Sakhr atau 'Umair bin 'Amir bin Zi asy-Syarri bin Thaif bin 'Ayyan bin Sa'b bin Hunain bin Sa'ad bin Tsa labah bin Salim bin Fahmi bin Ganam, 'Abdullah bin 'A'idz, 'Abdullah bin 'Amir, Sa'id bin al-Harits dll (banyak terjadi perbedaan). ${ }^{30}$ Namun beliau terkenal dengan nama Abu Hurairah.

b. Tingkatan : Sahabat

c. Lahir : $-\mathrm{H}$

d. Wafat :Madinah, $57 \mathrm{H}$ (adayang berpendapat 58 $\mathrm{H}$ dan $59 \mathrm{H})^{31}$

e. Nasab : Ad-Dusial-Yamani

f. Guru dan Muridnya:

1). Guru : Nabi Muhammad SAW., Abu Bakr ashShiddiqi, 'Umar bin Khattab, 'Ustman bin 'Affan, 'Ali bin Abi Thalib, 'Aisyah, Fadl 'Abbas bin 'Abd Muthalib, Ubay bin Ka'ab bin Qais, Usamah bin Zaidbin Haristah bin Syar Hubail, Bashrah bin Abi Bashrah, Hasan bin Tsabit bin al-Mundhir, Humail bin Bashrah bin Waqash, Sa'ad bin Malik bin Sanan bin 'Ubaid, 'Ustman bin Zaid.

29 Syuhudi Isma'il, Kaedah Kesahihan Sanad Hadis ..., h. 70.

30 DVD, al-Maktabah al-Syamilah al-Ihdar al-Tsani.

31 Ibid. Abu Hurairah meninggal pada tahun $57 \mathrm{H}$ menurut 'Aisyah, Abu al-Hasan al-Madaani, 'Ali Ibn al-Madini, Yahya bin Bakir, Khalifah bin Khiyath, dan 'Amru bin 'Ali. Tahun $57 \mathrm{H}$ menurut dhamran bin Rabi'ah, al-Haitsam bin 'Adi. Sednagkan 59 H menurut al-Waqidi, Abu 'Ubaid.dll 
2). Murid: al-Muharrir (anaknya) Ibrahim bin Isma'il, Ibrahim bin 'Abdullah bin Qaridl, Ibrahim bin 'Abdullah bin Hunain, , Abu al-Shalat 'an Abi Hurairah, Ibn 'Abbas, Ibn 'Umar, Jabir, Marwan bin al-Hakam, Sa'id bin al-Musayyab, 'Abdullah bin 'Abd ar-Rahman, Atha' bin Yazid al-Laisi, Yusuf bin Mahak, Abu shalih bin al-Saman, Na'im bin 'Abdullahal-Mujmar, Hamam bin Munabih, Abu Zar'ah bin 'Amru bin Harir bin 'Abdullah, Abu Ayub, Abu Bakar bin Sulaiman bin Abi Hastmat, 'Abdullah bin Khudaiffah, Abu Bakar bin 'Abd arRahman, bin al-harist bin Hisyam bin al-Mughirah, Abu Ja'far, Abu Hamid Maula Musafi', Abu Khalid Maula Ali Ja'dah, Abu Zaid bin Abi Hurairah, Abu Sa'd, Abu Sa'id, Abu Sa'id bin al-Ma'la, Abu alHakim, Abu al-Rabi', Abu Sa'id Maula 'Abdullah bin 'Am bin Kariz, Abu sufyan Maula 'Abdullah bin Abi Ahmad bin Jahsy, Ishaq Maula Zaidah, Aswad bin Hilal, Anas bin Hakim, Anas bin Malik, 'Uwais bin Khalid, 'Abdullah bin Syaqiq, Abdullah bin Dhamrah, dan lain-lain.

g. Pandangan kritikus hadis:

Al-Bukhari : kurang lebih 800 orangyang mengambil riwayat darinya, baik dari kalangan sahabat, tabi'in maupun lainnya.

Al-A'raj : Abu Hurairah paling banyak meriwayatkan hadis dari Rasulullah.

Ibn 'Umar : Abu Hurairah adalah seorang yang lebih baik dan tahu (tentang hadis) dariku.

Menurut para kritikus hadis, kedudukan Abu Hurairah sebagai sahabat tingkat pertama dalam meriwayatkan hadis tidak ada yang menyangkal. Seluruh jumhūr al-hadìs menyatakan bahwa Abu Hurairah adalah śiqat, d̦ābit, 'adil, dan hafidz. Oleh karena akurasi hadis yang diriwayatkannya 
tidak diragukan kebenarannya.

Mengenai persambungan sanad antara Abu Hurairah dan 'Abdullah bin Dhamrah as-Saluli diketahui sangat muttaşil. Ada beberapa bukti nyata yang dapat diajukan, yaitu: pertama bahwa keduanya memiliki hubungan yang dekat debagai guru dan murid. Kedua, dilihat dari tingkatan 'Abdullah bin Dhamrah as-Saluli sebagai tabi'în (orangyang pernah bertemu sahabat), maka sangat besar kemungkinan ia bertemu langsung (liqa $\left.\bar{a}^{\prime}\right)$ dengan $\mathrm{Abu}$ Hurairah walaupun kapan ia wafat tidak dapat dilacak. Ketiga, bertemunya secara langsung antar keduanya dapat dilihat dari metode periwayatan adalah as-sama' dengan tahammul wa al-'ada' yang menggunakan lafadz (haddatsana) yang menurut Ibnu Hajar al-'Asqalani menunjukkan bahwa periwayat mendengar sendiri. ${ }^{32}$

\section{MENELITI KEMUNGKINAN SYUŻŪŻ DAN ‘ILLAH}

I'tibar terhadap hadis riwayat Ibnu Majah no. 4102 semakin menunjukkan adanya syahid dan mutabi'. Syahid pada hadis ini adalah Ka'ab yang sama-sama mendapatkan hadis dari Nabi Muhammad SAW bersama Abu Hurairah. Adapun mutabi'terdapat pada sanadsanad pertama, kedua, ketiga, dan kelima. Kecuali sanad keempat (Abd ar-Rahman bin Tsabit bin Tsauban asy-Syami) dan keenam (Abdullah bin Dhamrah) tidak terdapat. Kekuatan hadis semakin meningkat apabila dikaitkan dengan adanya syahid yang samasama merupakan periwayat yang terpercaya dan beberapa mutabi ${ }^{6}$ pada beberapa sanadnya walaupun dengan tahammul wa al-'ada' yang tidak semuanya menunjukkan adanya penyampaian langsung antar perawi, seperti pemakaian lafadz 'an pada beberapa rawi.

Pada jalur riwayat Ibnu Majah terdapat para perawi yang dianggap śiqah atau kredibel, kecuali pada diri Abd ar-Rahman bin Tsabit bin Tsauban asy-Syami. terdapat berbagai kritikanyang

\footnotetext{
32 Syuhudi Isma'il, Kaedah Kesahihan Sanad Hadis ..., h. 60.
} 
melemahkannya sebagai perawi yang śiqat. Namun dengan berbagai penyelidikan yang mendalam oleh para ahli hadis terlacak bahwa kelemahan-kelemahan itu terjadi diakhir riwayat kehidupannya yang mengalami junna (pikun). Akan tetapi pada waktu hadis ini disampaikan kepada muridnya ('Utbah bin Hammad bin Khulaid) terbukti belum mengalami kekacauan sehingga ia dikatakan śiqah dalam riwayat ini sebagaimana dikatakan oleh para kritikus karena belum mengalamikekacauan.

Dengan berbagai alasan tersebut, dapat dikatakan bahwa sangat kecil kemungkinannya bahwa sanad jalur Ibnu Majah ini mengandung syuż̇̇̇ (kejanggalan) ataupun 'illah (cacat).

\section{E. KESIMPULAN}

Berdasar pada beberapa analisa terhadap hadis riwayat Ibnu majah no. 4201 di atas, terlihat bahwa seluruh periwayat hadis bersifat śiqat. Adapun mengenai ketersambungan sanad antar perawi jelas muttaşil dari sumbernya, Nabi Muhammad SAW, sampai kepada periwayat terakhir Ibnu Majah yang sekaligus sebagai mukharrij al-hadis dan tidak terdapat adanya syużüz (kejanggalan) ataupun 'illah (cacat) walauapun dengan tahammul wa al-'ada' yang tidak semuanya menunjukkan adanya penyampaian langsung antar perawi, seperti pemakaian lafadz' an pada beberapa rawi.

Melihat kejelasan kualitas para rawi, ketersambungan sanad dan terhindarannya dari syużüż (kejanggalan) ataupun 'illah (cacat), maka hal ini berarti sanad hadis yang diteliti, sanad hadis tentang "dunia dan segala isinya dilaknati kecuali dzikr al-Allah" yang diriwayatkan oleh Ibnu Majah dan at-Turmudzi serta didukung riwayat ad-Darimi memiliki kualitas hasan li ghairih.[]

Wallahu a'lam bi ash-shawab 


\section{DAFTAR PUSTAKA}

Ahmad, M. dan M. Musdzakir, Ulumul Hadis Untuk Fakultas Tarbiyah Komponen MKDK, Bandung: CV Pustaka Setia.

Al-'Asqalani, Ibn Hajar. Tahdhib al-Tahdhib, Juz VII. Beirut: Dar Shadir, t.t.

Al-Bukhari, Ibrahim al-Ja'fi. Kitab at-Tarih al-Kabir, Jilid VI. Beirut:

Dar al-Kutub al- 'Ilmiyyah, t.t.

Adz-Dzahabi.al-Kasyiffi Ma'rifahman lahu Riwayah fial-KutubalSittah, Juz II (Tahqiq) 'Azzad 'Ali 'and 'Atiyyah dan Musa M. 'Ali al-Musyi , T.t.p.: Dar al-Kutub al-Haditsah, t.t. , Mizan al-I'tidal fi Naqd al-Rija.l Juz II (Tahqiq) 'Ali Muhammad al-Bajawi, T.t.p.: Dar Akhya' al-Kutub al'Arabiyyah, t.t.

Isma'il, M. Syuhudi. Kaedah Kesahihan Sanad Hadis: Telaah Kritik dan Tajam dengan Pendekatan Ilmu Sejarah, Jakarta: Bulan Bintang, 1988.

, Metodologi Penelitian Hadi, Jakarta: Bulan Bintang, 1992.

Rahman, Fathur. IkhtisarMusthalahul Hadis, Bandung: PT. Ma'rif, 1991.

Suryadi, Metodologi Ilmu Rijalil Hadis, Yogyakarta, Madani Pustaka Hikmah, cet. 1, 2003.

CD-Rom, Mausu'ah al-Hadis asy-Syarif al-Kutub al-Tis'ah.

DVD, al-Maktabah asy-Syamilah al-Ihdar al-Tsani. 